\title{
PERANCANGAN MEDIA INTERAKTIF 3D VIRTUAL ENVIRONMENT SEBAGAI MEDIA INFORMASI PENGENALAN FASILITAS AKADEMIK UNIVERSITAS PRADITA
}

\author{
Fachri Fahrezi ${ }^{1}$, Nugroho W.P Utomo², Ardi Makki Pantow Gunawan ${ }^{3}$ \\ 1,2,3Program Studi Desain Komunikasi Visual, Universitas Pradita, \\ Banten,Indonesia
}

E-mail: fachri.fahrezi@student.pradita.ac.id, nugroho.widya@pradita.ac.id, ardi.makki@pradita.ac.id

\begin{tabular}{l|l|l} 
Received : Month, Year & Accepted : Month, Year & Published : Month, Year
\end{tabular}

\begin{abstract}
The introduction of information about academic facilities is still commonplace with print media such as posters, banners, banners, brochures, flyers and the like to digital media such as infographics, websites and social media. Following the development of technology trends, interactive virtual media is very popular because it has interactive feedback to the user and can be accessed through devices/gadgets. Pradita University still uses social media, Youtube and websites as its communication strategy in communicating academic facilities, these media cannot represent spatial matters. The design of Interactive 3D Virtual Environment media can answer this because this media can represent spatial information related to academic facilities virtually with full con trol by the user so that the user is directed to know the location of all academic facilities.
\end{abstract}

Keywords: Interactive, User, 3D Virtual Environment

\begin{abstract}
Abstrak
Pengenalan informasi mengenai fasilitas akademik masih lumrah dilakukan dengan media cetak seperti poster,banner,spanduk,brosur,flyer dan sejenisnya sampai media digital seperti infografis,website dan media sosial. Mengikuti perkembangan trend teknologi, media virtual interaktif sangat populer digunakan dikarenakan memiliki interactive feedback kepada user dan dapat diakses melalui device/gadget. Universitas Pradita masih menggunakan sosial media, Youtube dan website sebagai strategi komunikasinya dalam mengkomunikasikan fasilitas akademik, media tersebut tidak dapat merepresentasikan hal-hal yang terkait spasial. Perancangan media Interaktif 3D Virtual Environment bisa menjawab hal tersebut dikarenakan media ini dapat merepresentasikan informasi spasial terkait fasilitas akademik secara virtual dengan kontrol penuh oleh user sehingga user diarahkan untuk mengetahui letak tempat seluruh fasilitas akademik yang direpresentasikan secara imersif.
\end{abstract}

Kata Kunci: Interaktif, User, 3D Virtual Environment

1.

PENDAHULUAN

Perkembangan teknologi yang semakin pesat mengubah kebiasaan masyarakat umum dalam mencari informasi dengan menggunakan media interaktif, terutama untuk mencari informasi mengenai seputar dunia pendidikan dalam konteks Universitas. Banyak sekali penyajian informasi yang membosankan karena dilihat statis dan tidak memiliki nilai interaksi sehingga informasi tersebut tidak dapat berkomunikasi dengan baik untuk orang yang melihatnya, sarana penyediaan informasi dalam bentuk media interaktif virtual menjadi kegiatan yang sangat populer dikarenakan media virtual bisa menampilkan lingkungan maya dengan sangat representatif dan memiliki umpan balik terhadap orang yang melihat informasi tersebut, lingkungan fisik yang hidup dan dapat dikendalikan dengan menggunakan device/gadget. Universitas Pradita merupakan Perguruan Tinggi Swasta (PTS) yang dibangun oleh PT. Summarecon Agung Group berdiri dari tahun 2016 memiliki lokasi yang terletak di 
provinsi Banten kota Tangerang Gading Serpong. Universitas Pradita memiliki fasilitas yang menunjang kegiatan akademik dan non-akademik.

Universitas Pradita sendiri menggunakan media cetak seperti poster flyer hingga banner dan media digital seperti website, poster digital, infografis serta video dalam melakukan publikasi-publikasi terkait informasi mengenai kegiatan akademik maupun non akademik, program studi, beasiswa, harga, lokasi gedung hingga fasilitas selain sebagai bentuk marketingnya tetapi juga untuk membagikan eksistensinya sebagai PTS. Ditambah pengelolaan media sosial yang terintegrasi dengan baik dengan menyajikan konten yang bersumber dari mahasiswa itu sendiri. Mengenai penyajian informasi terkait gedung dan fasilitas yang dilakukan oleh Pradita University tidak cukup representatif dikarenakan informasi yang harus disajikan berkaitan erat dengan lingkungan dari segi bangunan suasana sampai skenario cara menggunakan fasilitas yang tersedia. Mengingat adanya calon mahasiswa dan masyarakat umum yang ingin mengetahui mengenai fasilitas pendidikan akademik dengan tidak harus datang ke tempat terutama dengan adanya beberapa kondisi khusus seperti pandemi Covid19 yang membatasi orang untuk datang ke dalam ruang gerak publik.

Perancangan 3D Virtual Environment Sebagai Media Informasi Pengenalan Fasilitas Pendidikan Universitas Pradita dapat menjadi solusi dalam merepresentasikan lingkungan universitasnya yang memiliki nilai interaktif dilengkapi oleh penggambaran lingkungan hidup disertai dengan simulasi fisik dan karakter yang ekspresif dan dapat digerakkan menggunakan device/gadget pengguna itu sendiri, memiliki implementasi berupa proyeksi komputer secara virtual disertai dengan pemahaman mengenai Environmental Graphic Design yang memiliki spektrum terkait signage and wayfinding, interpretation dan Placemaking.

\section{Virtual Environment}

Virtual Environment (VEs), yang difokuskan pada komponen kognitif dan proses perhatian, baru-baru ini dikembangkan dan divalidasi untuk kemampuan spasial (Rizzo et al., 2006), pembelajaran dan memori, dan fungsi eksekutif. Kemampuan VE untuk menciptakan lingkungan tiga dimensi yang dinamis, imersif, di mana respons perilaku dapat direkam, menawarkan sejumlah opsi penilaian dan rehabilitasi yang tidak tersedia dengan metode penilaian tradisional. VEs adalah lingkungan sintetis imersif yang memungkinkan operator memahami skema mekanisme suatu proses, tidak hanya pada tingkat representasi. Ini juga memungkinkan memberikan simulasi mengenai perasaan dan emosi yang sesuai, yaitu yang dirasakan dalam kenyataan. Operator, selama penggunanya virtual environment dapat memberikan pengalaman berupa kehadiran fisiknya di dalam lingkungan yang diberikan.

\section{Virtual Environment Display}

Virtual environment display merupakan tampilan komputer yang memberikan gambar kepada pengguna berupa ilusi perpindahan ke lokasi lain. Istilah yang berbeda telah diterapkan pada illusion. Beberapa, seperti artificial reality (realitas buatan) dan virtual reality (realitas maya) secara oxymoronic. Virtual environment display dapat didefinisikan sebagai lingkungan virtual dengan tampilan gambar yang interaktif dan virtual diperkuat oleh pemrosesan khusus untuk meyakinkan pengguna bahwa mereka tenggelam dalam ruang sintetis (Ellis).

\section{Environmental Graphic Design}

Environmental Graphic Design Environmental Graphic Design atau biasa disingkat EGD adalah komunikasi grafis mengenai sebuah informasi yang ditemukan dalam sebuah lingkungan (environment) (Calori and VandenEynden 2015). Pemahaman dari Calori menegaskan bahwa EGD adalah sebuah disiplin ilmu yang berkaitan dengan desain grafis, bukan hanya arsitektur dan juga interior. Signifikansi lain dari pemahaman yang dipaparkan oleh Calori adalah bahwa perancangan grafis tidak serta merta hanya pada lingkup dua dimensi saja, namun dapat secara tiga dimensi (Hananto 2017).

Terdapat tiga komponen utama dalam EGD:

1. Signage dan wayfinding, dimana EGD berfungsi untuk menuntun dan membawa audiens kepada sebuah tempat dengan menunjukan jalan. 
2. Placemaking, dimana EGD berfungsi untuk memberikan identitas terhadap sebuah lokasi, dengan demikian tempat itu dapat dikenali dan lebih mudah diingat

3. Interpretation, dimana EGD berfungsi memaparkan informasi terhadap sebuah tempat atau lokasi dan informasi tersebut dapat diinterpretasi dan dimengerti.

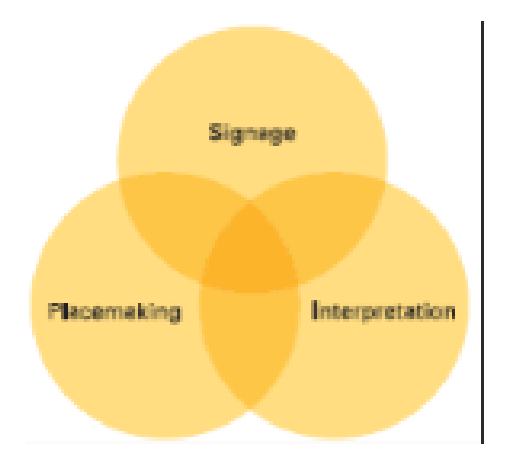

\section{Gambar 1. The three components of EGD and how it can overlap (Sumber : "A Competitive Guide to Creating Environmental Graphics Design System Signage and WayFinding").}

\section{D Modeling}

3D modelling adalah hasil dari representasi dari proses secara matematika yang membentuk objek 3D. Hasil dari proses tersebut adalah apa yang sekarang ini disebut dengan 3D model atau 3D Mesh. Untuk memproduksi sebuah karya 3 dimensi yang baik, dapat dibagi menjadi beberapa tahapan produksi yang masing-masing dikerjakan oleh bagian-bagian yang berbeda, yakni : Story, Visual Design, Storyboard, Edit, Audio, Modelling, Scene Setup, Texturing, Rigging, Animation, Effects, Lighting, Rendering, Compositing.

\section{a. Nurb Surface}

Nurbs Surface merupakan model dengan permukaan yang halus biasa digunakan untuk untuk objek yang kurang memerlukan sudut tajam (slick,2020)

\section{b. Subdivision}

Subdivision Modelling merupakan teknik modeling polygonal 3D dimulai dengan bentuk geometris yang dikerjakan secara bertahap dari bentuk mesh resolusi rendah dan diulang terus menerus hingga mendapatkan detail untuk menyampaikan konsep 3D yang dimaksud. Pemodelan Subdivision hampir serupa dengan pemodelan polygon dikarenakan dibuat dari kumpulan titik-titik, edge dan polygon. Menciptakan lengkungan halus dan dapat dikontrol dengan simpul asli.

\section{c. Digital Sculpting}

Sculpt modeling merupakan modeling yang dilakukan dengan cara mematung seperti memahat tanah liat. Sculpt modeling digunakan untuk menciptakan bentuk model berbentuk organis dengan memiliki vertex yang banyak dan dimodifikasi menggunakan brush pada aplikasi model 3D

\section{Cel Shading}

Cel-shading atau toon shading adalah jenis render non-photorealistic dirancang untuk membuat komputer grafik 3D tampak datar dengan menggunakan kurang warna pada shading bukan dari gradient warna. cel-shading digunakan untuk meniru buku komik atau kartun. Hal mengenai cel-shading ini baru - baru muncul dalam dunia 
graphic komputer pada abad 21 ini. Nama cel berasal dari Celluloid, lembaran yang bening atau jelas yang di lukis untuk digunakan dalam animasi 2D. Teknik ini memiliki ciri-ciri yaitu adanya outline/garis pinggir yang tebal dan pencahayaan yang sederhana/kurang realistis.

\section{Proses Cel-Shading}

Proses cel-shading merupakan model 3D yang khas/tipikal. Yang membedakan Cel-shading dari render lain adalah dalam model pencahayaan non-fotorealistik nya. Nilai pencahayaan dihitung untuk setiap pixel dan kemudian dikuantisasi untuk sejumlah kecil warna diskrit untuk menciptakan karakteristik datar tampilan di mana bayangan dan highlights tampak lebih seperti blok warna daripada dicampur dengan cara yang halus. Hitam "tinta" Outline dapat dibuat dengan menggunakan berbagai metode. metode membuat garis hitam, sedikit lebih besar dari objek itu sendiri. Sehingga kesan Karakter akan terlihat seperti 2 Dimensi.

\section{Shading}

Efek shading yang dihasilkan dari gaya cel-shading dengan setiap sudut dari objek menentukan arah dan titik pencahayaan dengan menghitung konsinusnya masing - masing. Efeknya dihasilkan dari objek normal. Setiap normal memiliki sudutnya sendiri, yang ditentukan antara arah dan titik pencahayaan. Ini menghitung kosinus masing-masing dan menerapkan nada tertentu ke wajah/area itu. Kapan kedua arah normal dan cahaya cocok, nada akan lebih cerah. Ketika arah tidak cocok, sudut meningkat dan nadanya akan lebih gelap.

\section{Outline}

Untuk mencapai tampilan kartun terkadang grafik Cel Shading menyertakan garis hitam yang mensimulasikan goresan gambar, ini garis besar dihasilkan oleh teknik yang berbeda seperti Edge Detection atau Back Face Culling. Edge Detection atau Back Face Culling adalah dua teknik independen, tetapi karena fakta bahwa mereka digunakan hampir selalu dalam kombinasi dengan Cel Shading, itu umum untuk melihat teknik-teknik yang tercakup di bawah Cel Shading teknik.

\section{Texturing}

Tekstur untuk mencapai gaya kartun atau gambar didasarkan pada penggunaan tekstur yang dibuat khusus untuk tujuan ini

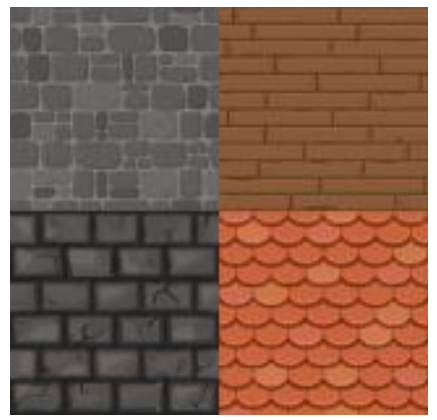

Gambar 2. Stylized Texture (Sumber: www.artstation.com/artwork/dO0qJw)

Menyertakan garis hitam dalam tekstur atau menggantinya dengan cara tradisional dengan kuas dan goresan yang terlihat. Program Menggabungkan fungsi shader tertentu untuk memasukkan tekstur artistik Anda sendiri. Salah satu contohnya adalah "Art Shader" dari Cinema 4D, di mana Anda dapat mengimpor tekstur dan menggunakannya sebagai bola biasa.

\section{Cahaya}


Cahaya merupakan salah satu bentuk energi yang dipancarkan oleh benda atau sumber cahaya dalam bentuk gelombang elektromagnetik (Setiawan, 2020). cahaya merupakan suatu gelombang elektromagnetikyang dapat ditangkap oleh matatelanjang, panjang gelombang elektromagnetik dari cahaya adalah sekitar $380-750 \mathrm{~nm}$. terdapat 2 macam sumber cahaya yang terdiri dari sumber cahaya alami seperti matahari dan sumber cahaya buatan seperti lampu. Cahaya merambat lurus, merupakan salah satu sifat cahaya. Salah satu bukti bahwa cahaya

merambat lurus adalah pada kasus lampu senter, saat senter diarahkan pada suatu lokasi maka cahaya akan mengikuti arah dari lampu tersebut diarahkan. Pada kasus lampu senter, Cahaya yang dipancarkan terlihat lebih tebal bila dibandingkan dengan sumber cahaya, hal tersebut berkaitan dengan sifat cahaya yaitu cahaya dapat dipantulkan. Pada bagian sekitar lampu senter terdapat suatu bahan mirip dengan cara kerja kaca yang dapat memantulkan cahaya sehingga cahaya dari lampu senter dapat dipantulkan ke segala arah dan dapat menyinari lebih banyak bidang. Sifat cahaya yang selanjutnya adalah cahaya dapat menembus benda bening seperti kaca, plastik bening.Sifat cahaya yang terakhir adalah cahaya dapat dibelokkan atau dibiaskan, sebagai kasus cahaya dapat dibiaskan atau dibelokkan adalah bila sebuah pensil dimasukkan dalam segelas air maka pensil akan terlihat seperti patah.

\section{METODE PENELITIAN}

Untuk menghasilkan penelitian yang sesuai dengan perancangan, peneliti perlu melakukan perencanaan dengan baik melalui tahapan penelitian. Adapun tahapan penelitian sebagai berikut:

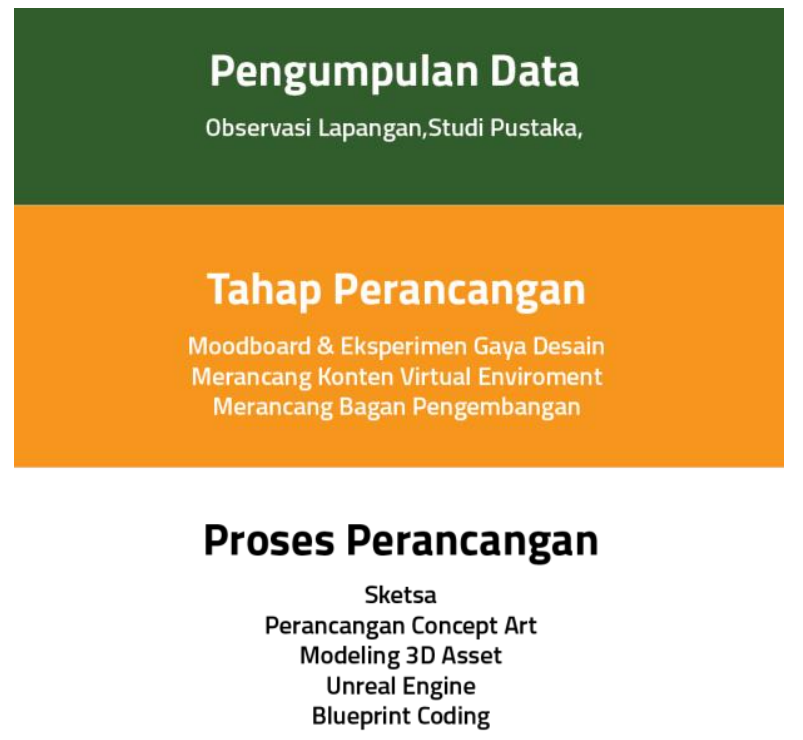

Gambar 3. Bagan Proses Perancangan

-Pengumpulan data dilakukan dengan menggunakan Observasi Lapangan terkait bagian Universitas Pradita dari segi eksterior, interior serta identitas visual terkait signage.

-Studi pustaka dari sumber jurnal diperlukan sebagai landasan teori yang akan digunakan.

-Wawancara merupakan data tambahan untuk perancangan terkait respon user terhadap interaktif virtual environment.

Perancangan dimulai dari proses moodboard dan eksperimen gaya desain sebagai pendekatan visual yang nanti akan digunakan untuk concept art, lalu dilanjutkan dengan pemetaan konten serta bagan pengembangan dan eksekusi modeling aset untuk virtual environment. Kompilasi akhir menggunakan software Unreal Engine untuk memuat seluruh aset visual serta membuat interaksi. 


\section{HASIL DAN PEMBAHASAN}

\subsection{Deskripsi Data}

\section{Observasi Lapangan}

Media Universitas Pradita

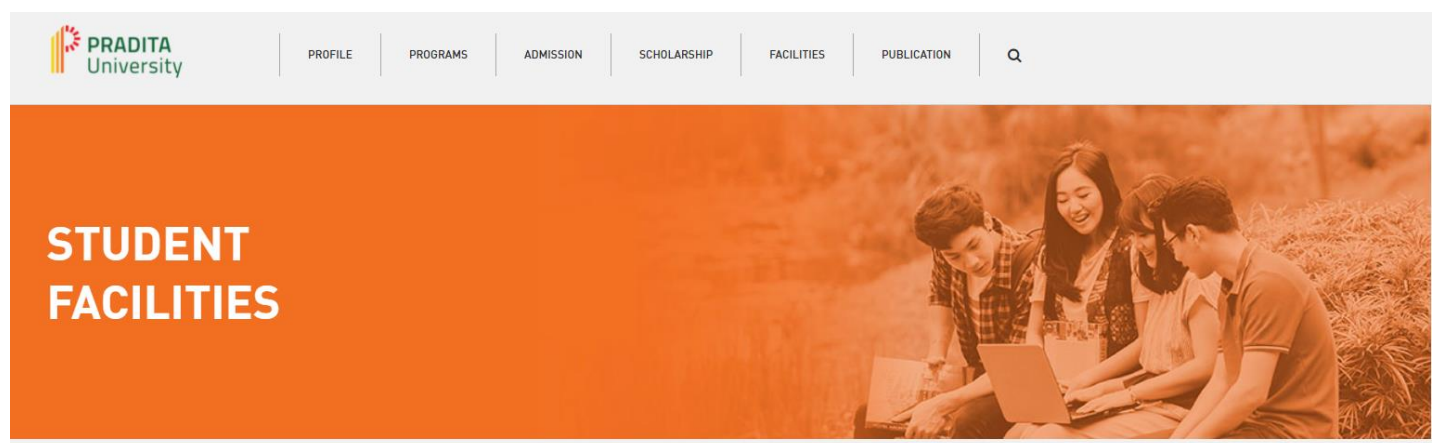

Sebagian besar waktu mahasiswa dihabiskan di luar kampus.

Karena itu, lingkungan sekitar kampus yang nyaman berikut fasilitasnya dapat menunjang kegiatan belajar dan keseharian mahasiswa. Kawasan

Summarecon Serpong seluas ratusan hektar akan menjadi lab untuk studi sekaligus tempat yang asyik buat menjalani aktivitas lainnya.

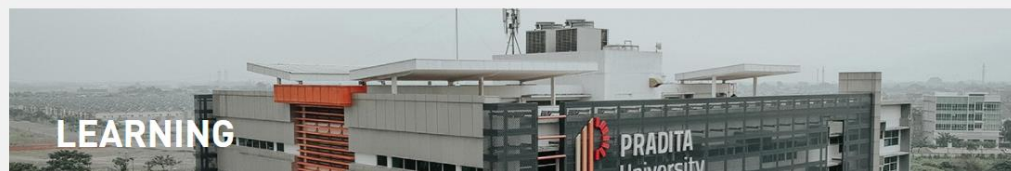

Halo, butun bantuan? Yuk chat sekarang!

Gambar 4. Website Universitas Pradita (sumber: pradita.ac.id)

Universitas Pradita menggunakan website sebagai media komunikasinya untuk masyarakat dalam menjelaskan fasilitas akademik.

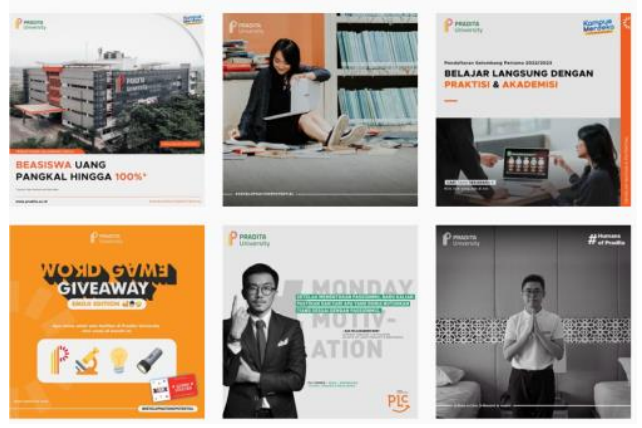

Gambar 5. Media Sosial Universitas Pradita (sumber: https://www.instagram.com/pradita.info/) 
Universitas Pradita juga menggunakan sosial media sebagai media komunikasinya dalam menyampaikan fasilitas akademik.

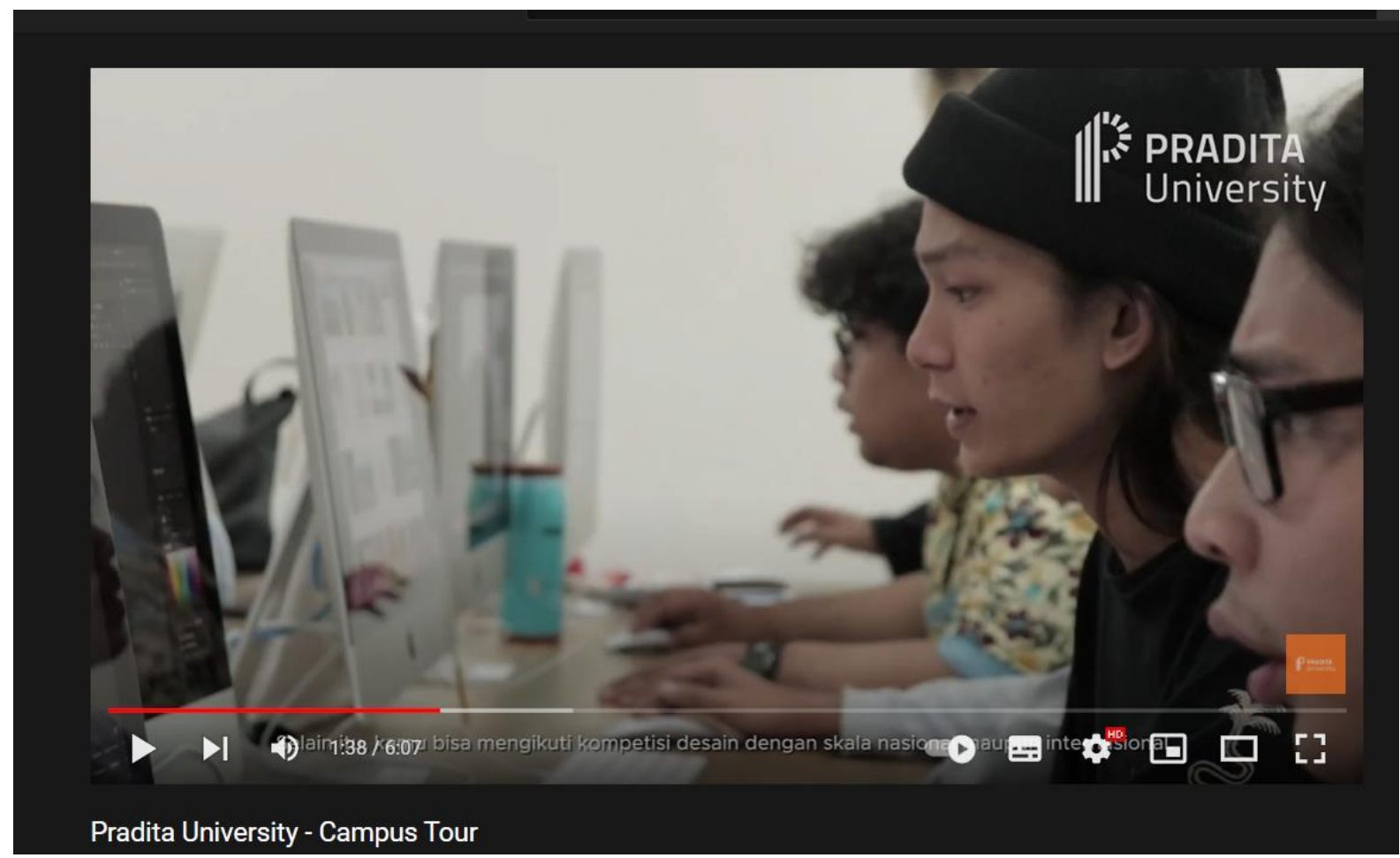

Gambar 6. Youtube Universitas Pradita

(sumber:https://www.youtube.com/watch?v=j1pATSO9vzU\&t=98s\&ab channel=PraditaUniversity)

Universitas Pradita juga menggunakan YouTube untuk mengenalkan fasilitas akademik Universitas Pradita.Dari data yang dikumpulkan oleh penulis Universitas Pradita menggunakan media online non-interaktif untuk mengkomunikasikan fasilitas akademik kepada user.

\section{Eksterior Universitas Pradita}

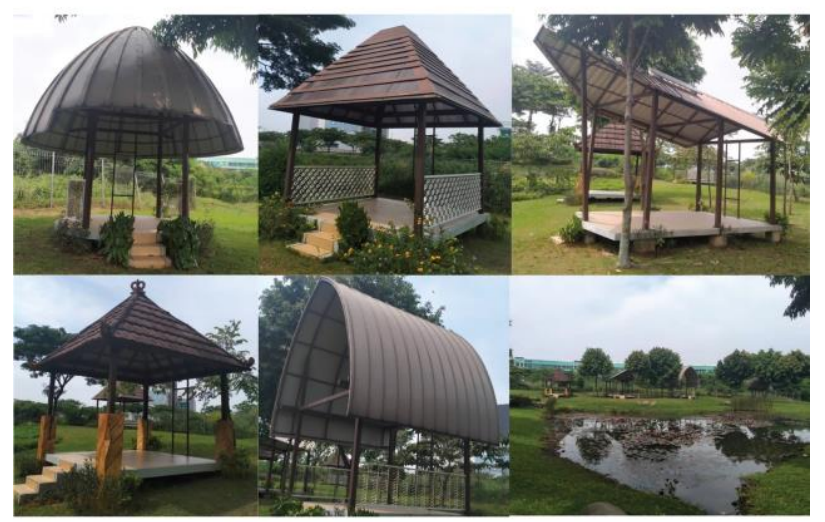

Gambar 7. Taman Kebangsaan Universitas Pradita (Sumber: Dokumentasi Pribadi, 2021) 
Observasi Lapangan bagian eksterior dilakukan untuk mengimplementasikan Universitas Pradita kedalam Virtual Environment. Terdapat beberapa bagian yang dikategorikan oleh penulis seperti bagian pintu masuk, bagian gedung pertama, bagian gedung kedua, taman kebangsaan dan jalan keluar Universitas Pradita.

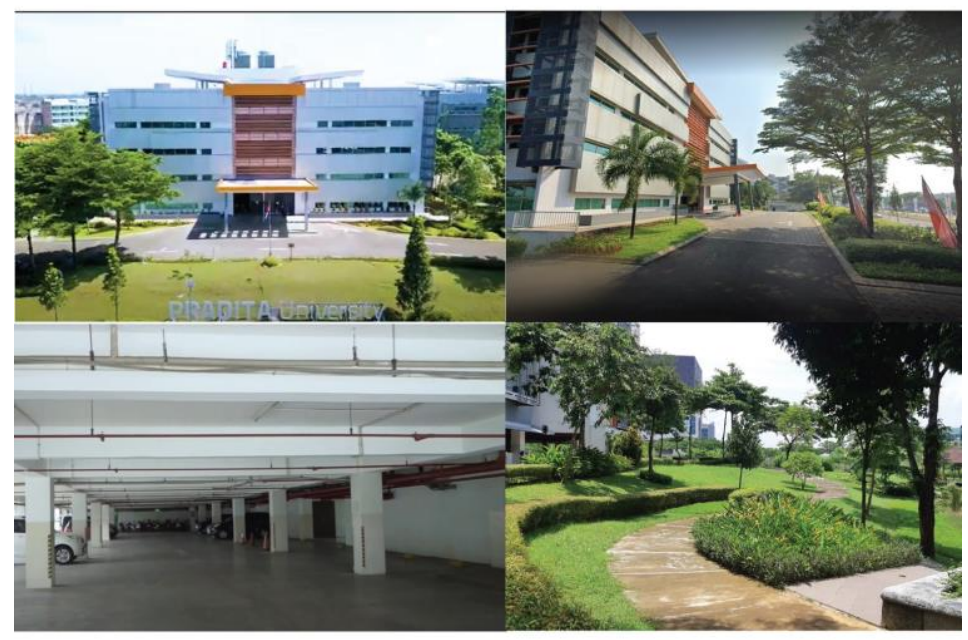

\section{Gambar 8. Dokumentasi Universitas Pradita (Sumber: Dokumentasi Pribadi, 2021)}

Dari hasil observasi bagian eksterior Universitas Pradita penulis akan mengimplementasikan kedalam bentuk modeling 3 dimensi. Seluruh gambar dapat dipastikan mengalami deformasi bentuk dan tinggi dikarenakan pendekatan yang digunakan hanya bertujuan untuk komunikasi visual.

\section{Interior Universitas Pradita}

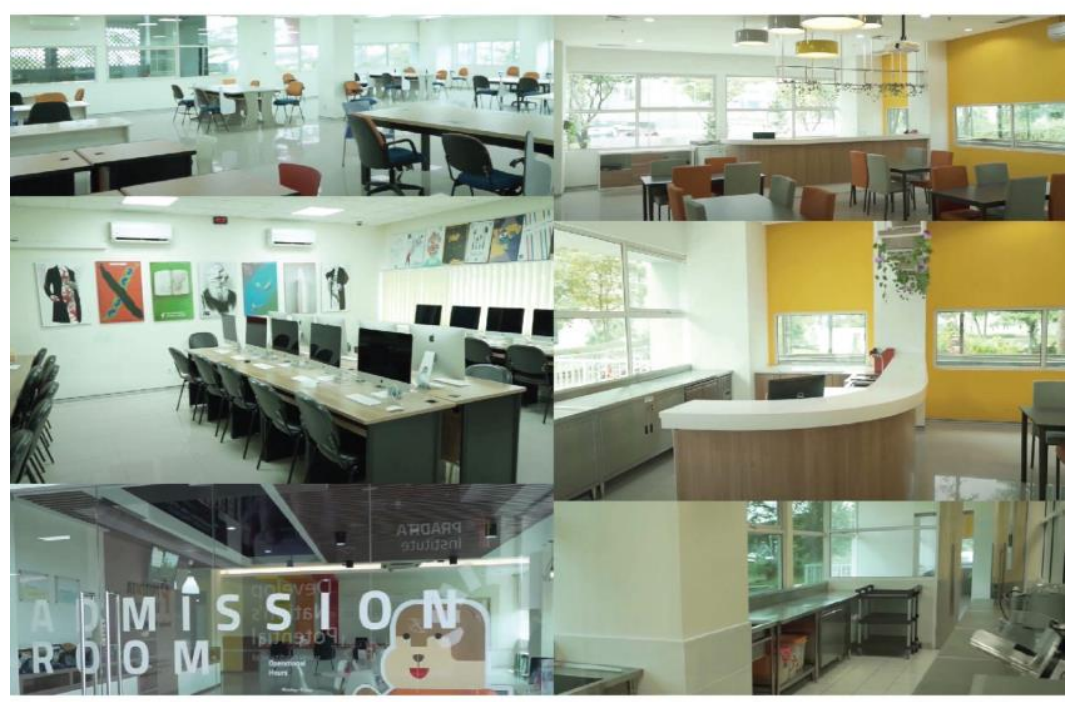

Gambar 9. Interior Universitas Pradita (Sumber: Dokumentasi Pribadi, 2021) 
Identitas Visual yang digunakan sebagai signage and wayfinding

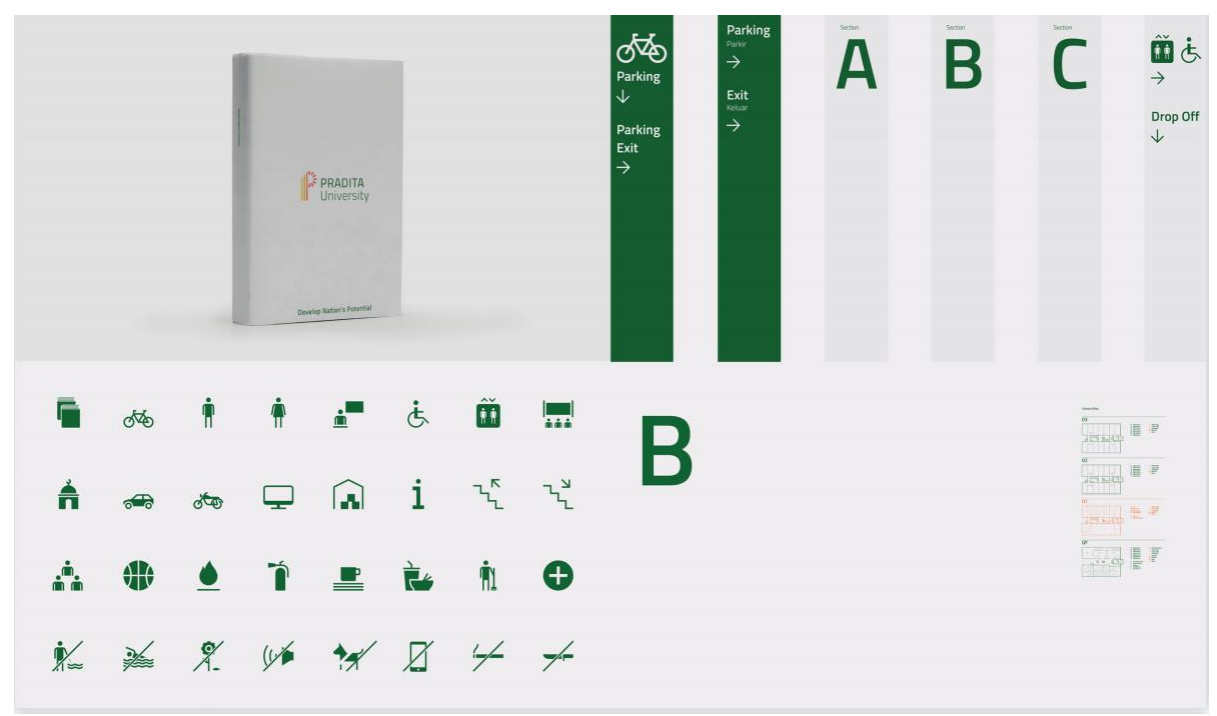

Gambar 10. Signage Universitas Pradita. (Sumber: Company Profile Nusae 2020)

Signage Universitas Pradita diperlukan untuk diimplementasikan kedalam virtual environment sebagai wayfinding.

\section{Moodboard dan Eksperimen Gaya Desain}

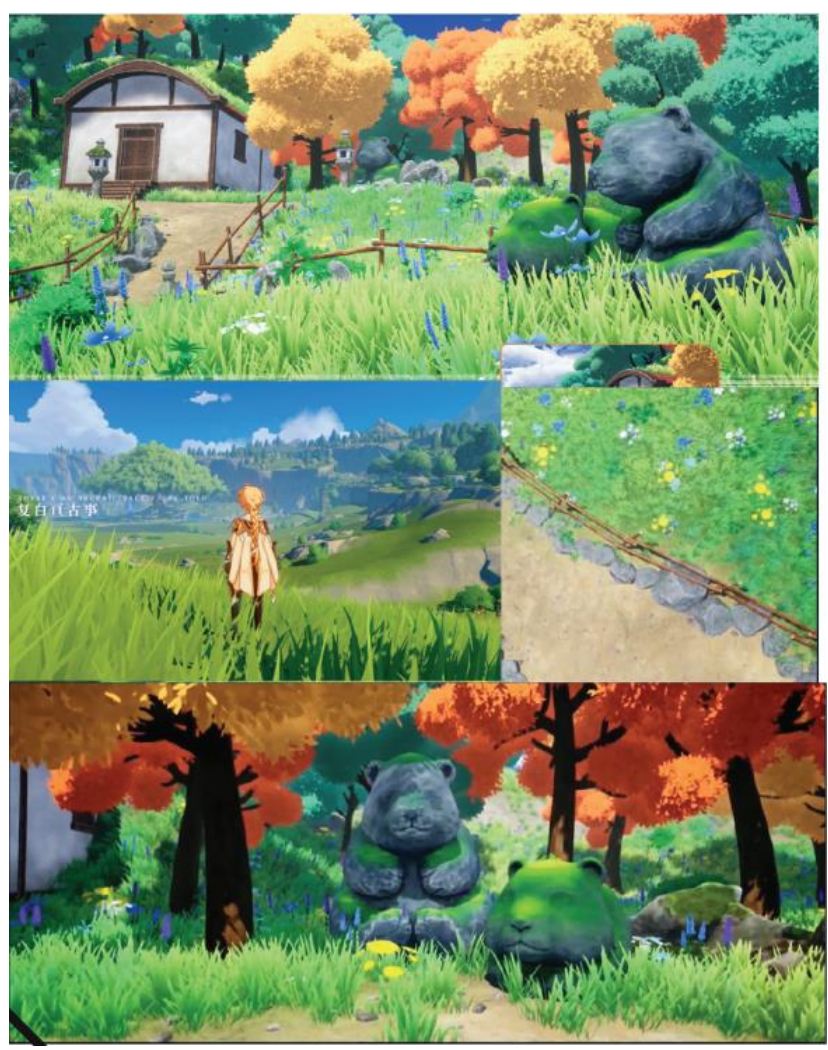


Gambar 11. Moodboard Perancangan Desain

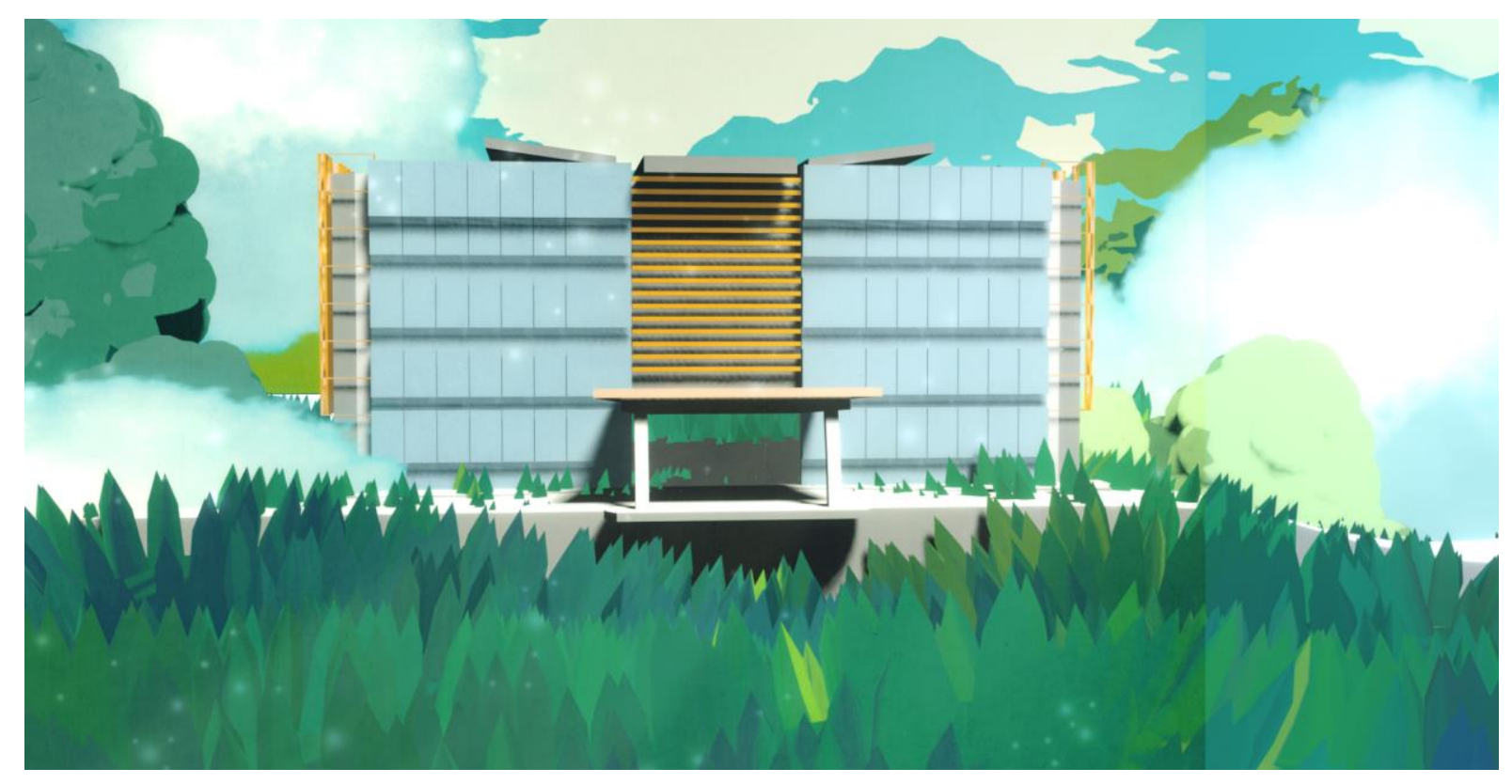

Gambar 12 . Eksperimen Gaya Desain (Sumber: Dokumentasi Pribadi, 2021)

Konten Virtual Environment.

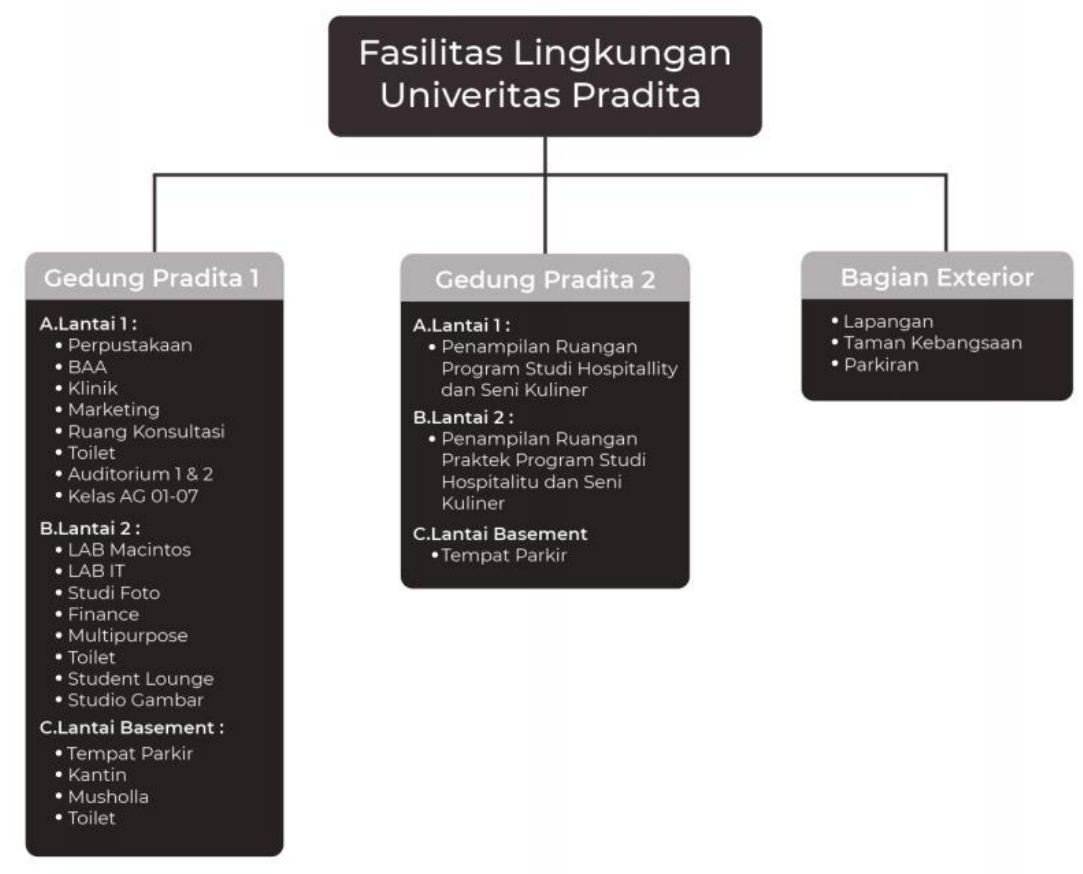




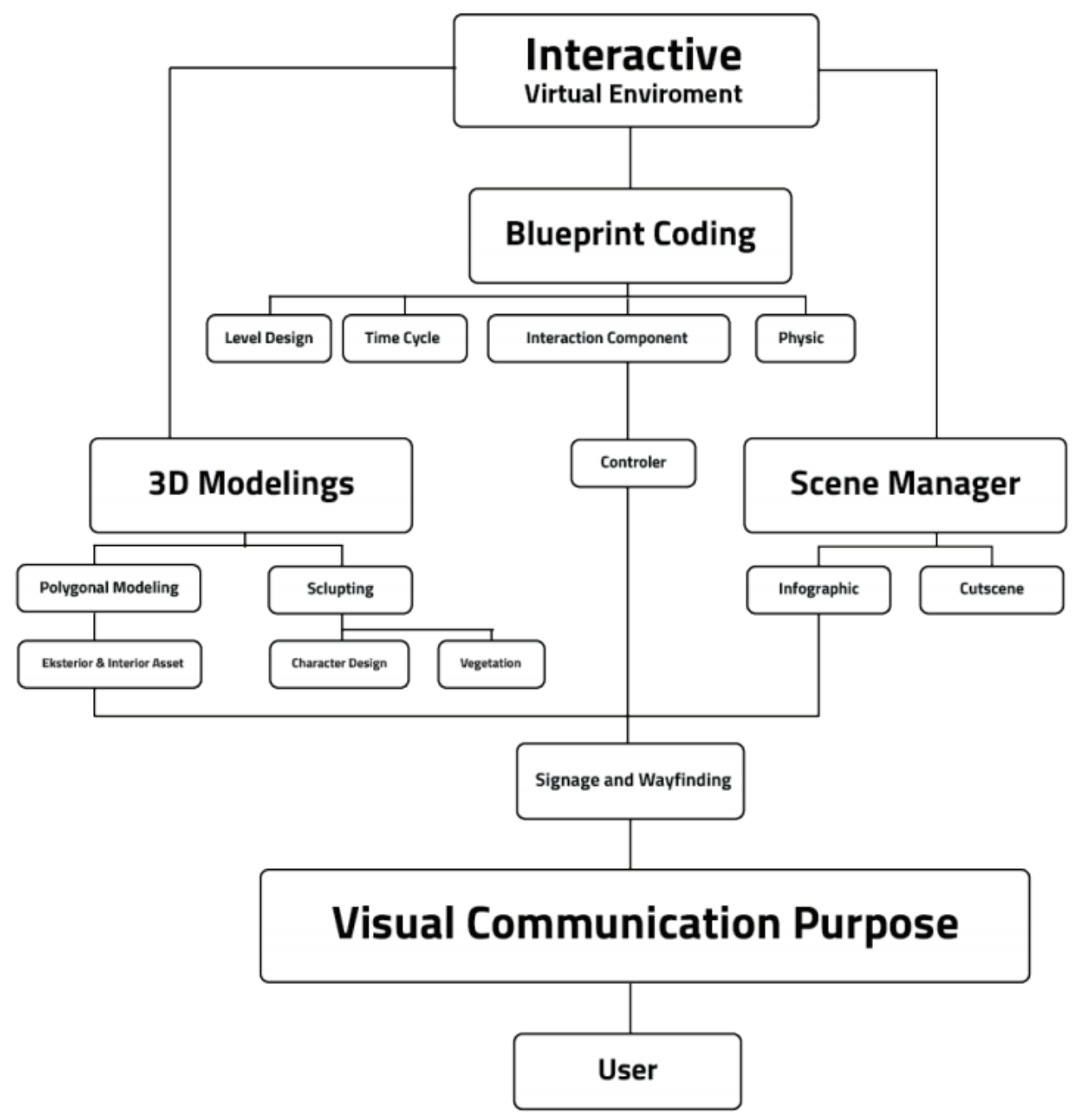

Gambar 14 . Bagan Pengembangan 


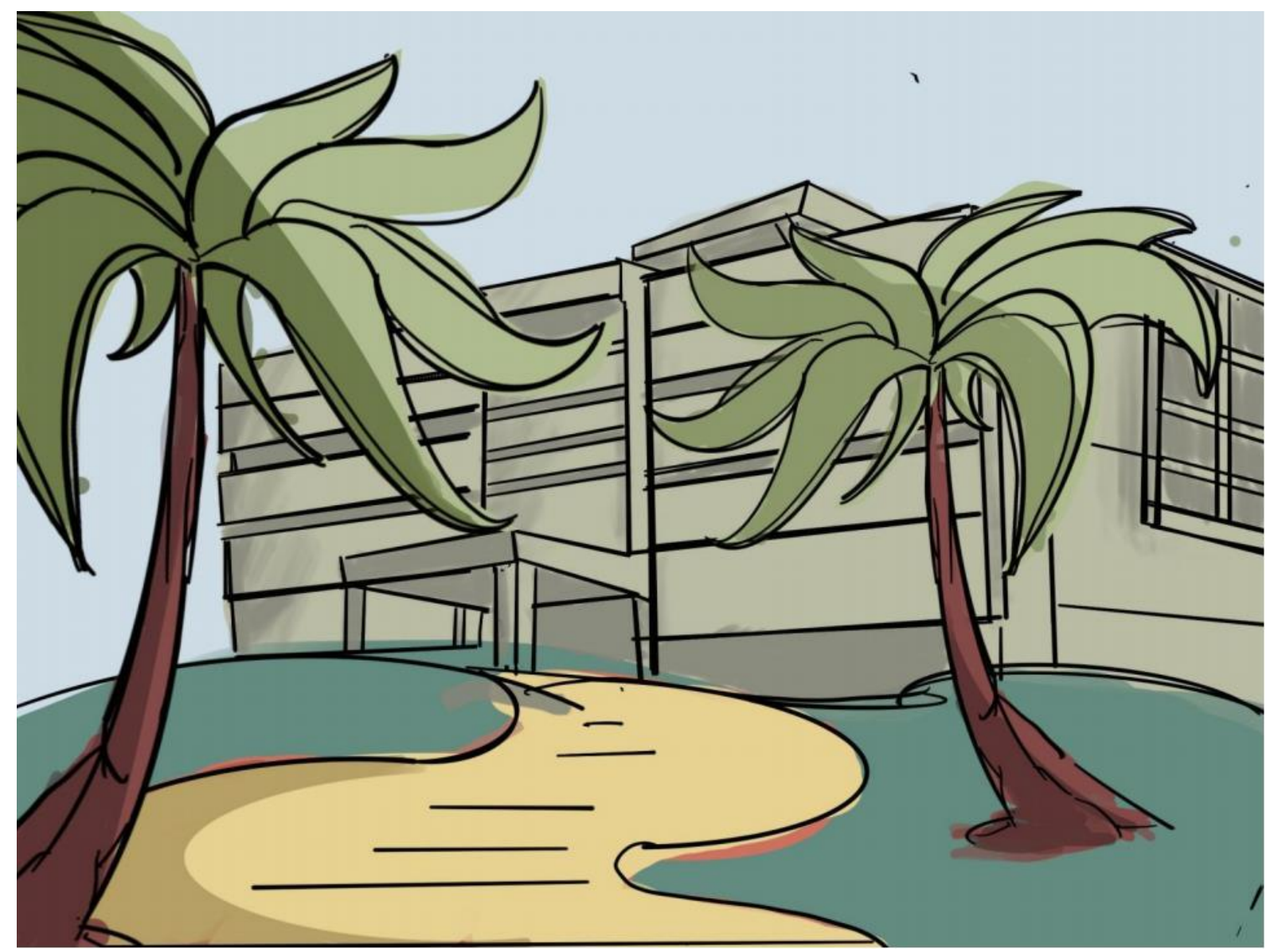

Gambar 15 . Sketsa

\section{Concept Art}

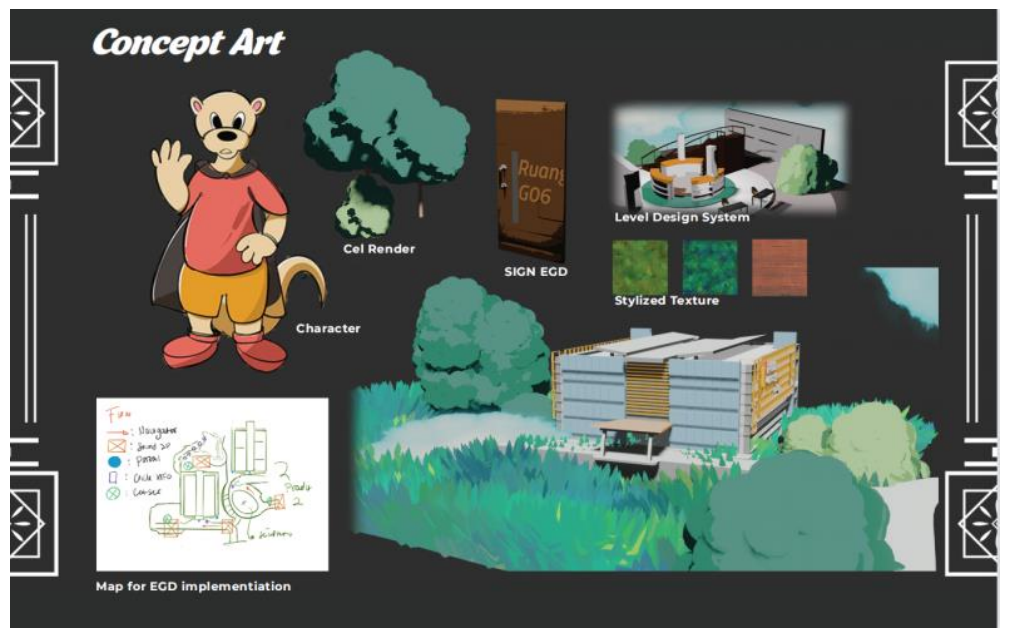




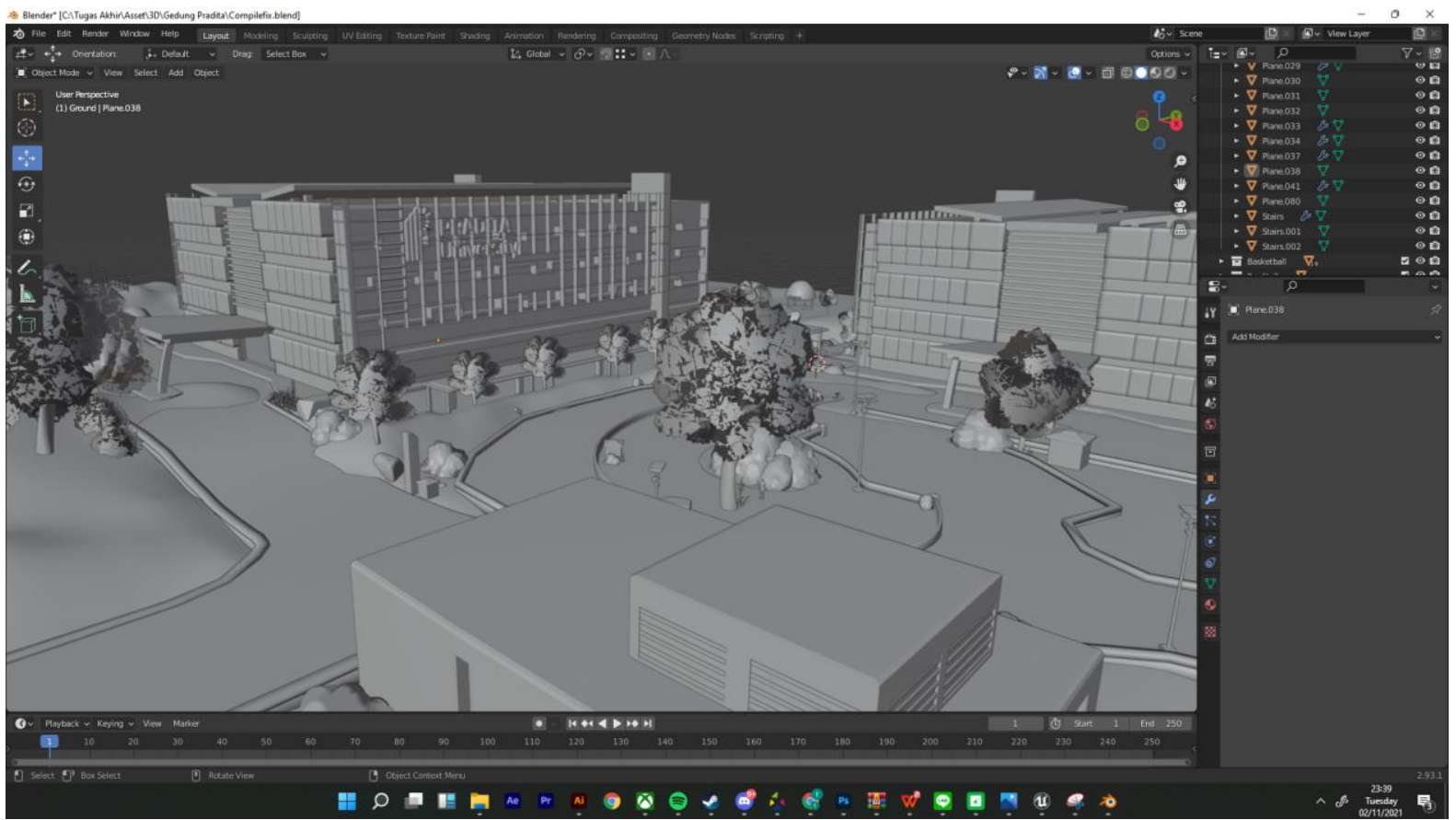

Gambar 17. Kompilasi aset 3D (Sumber: Dokumentasi Pribadi, 2021)

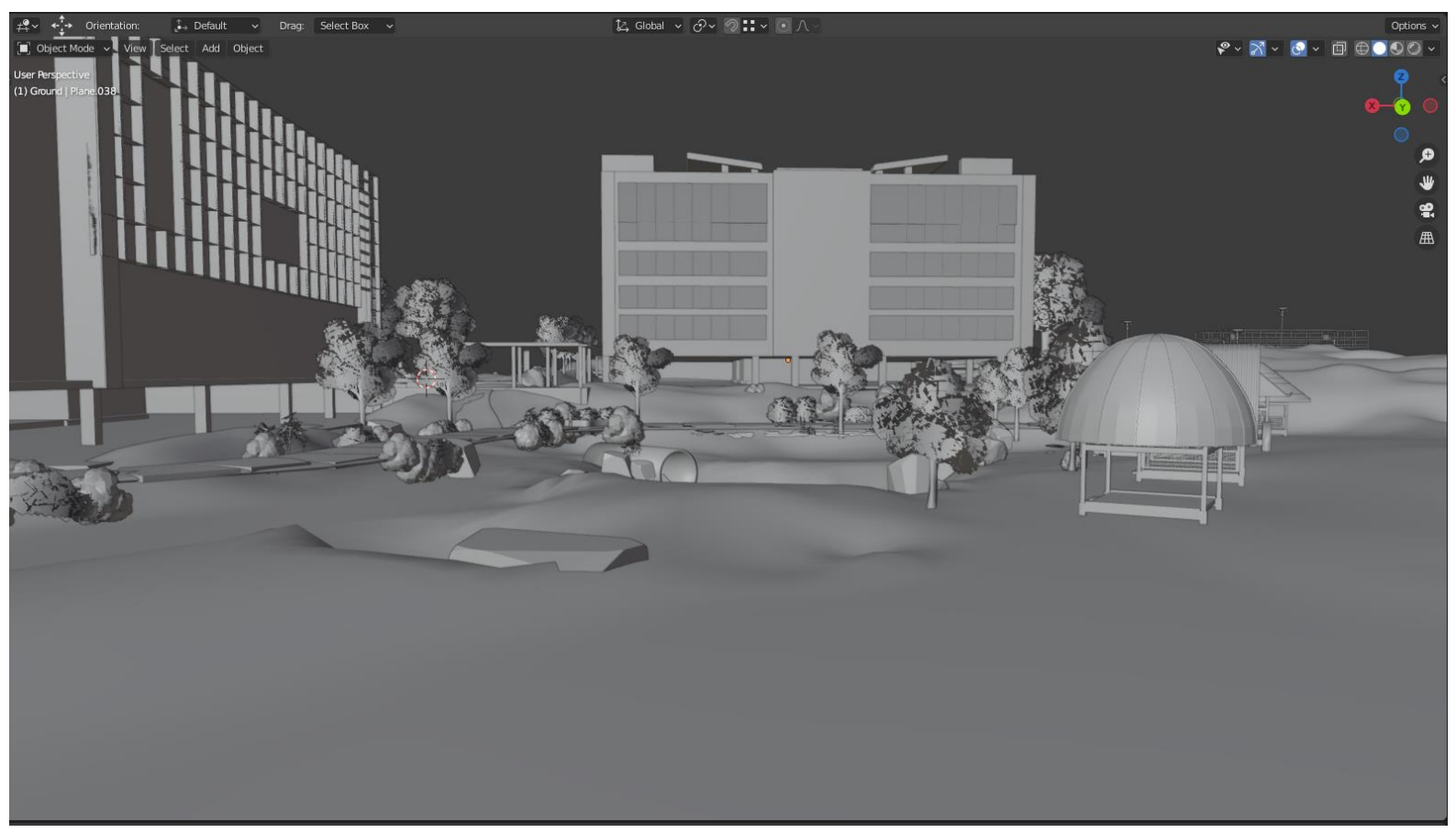

Gambar 18. Aset 3D Taman Kebangsaan (Sumber: Dokumentasi Pribadi, 2021) 


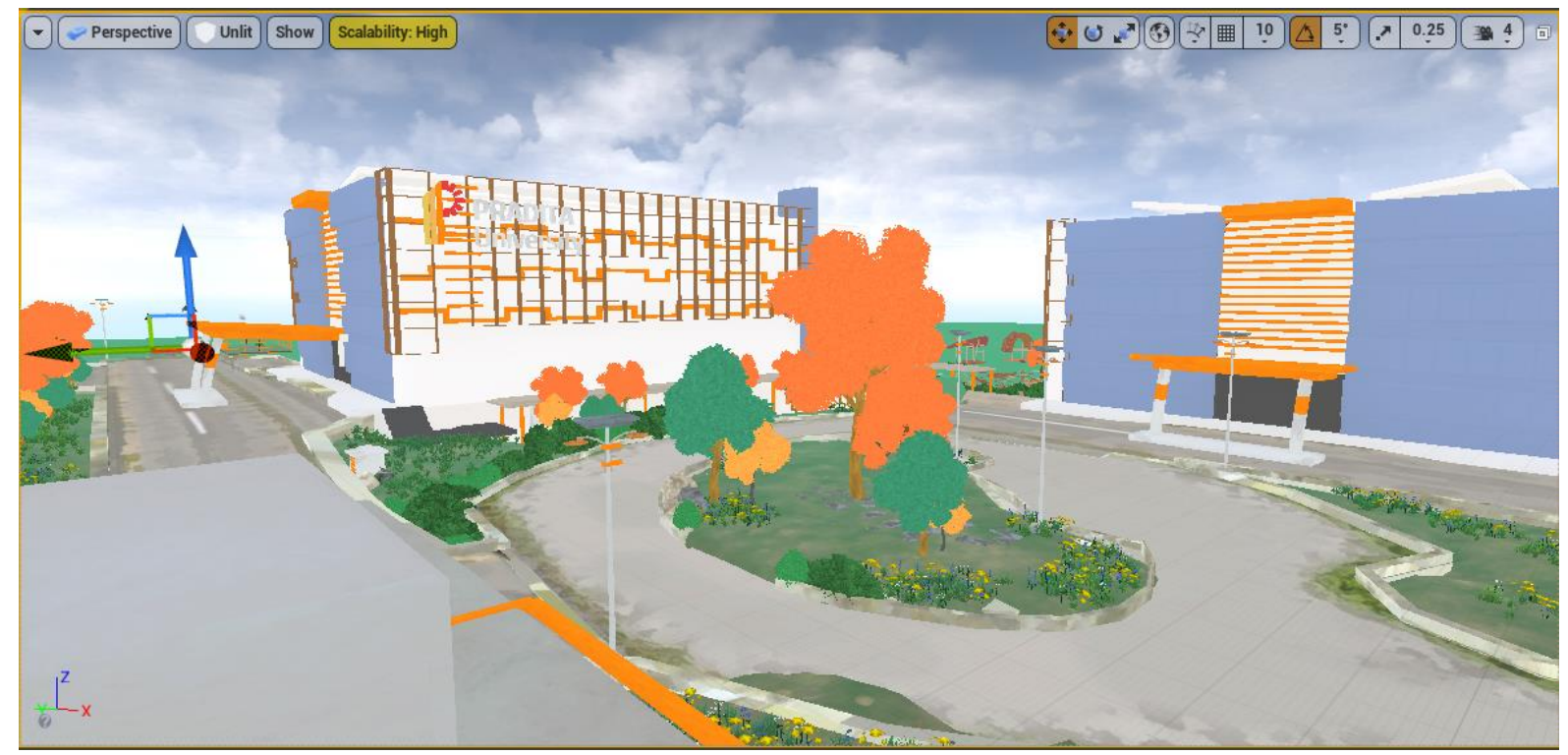

Gambar 19. Render Unreal Engine (Sumber: Dokumentasi Pribadi, 2021)

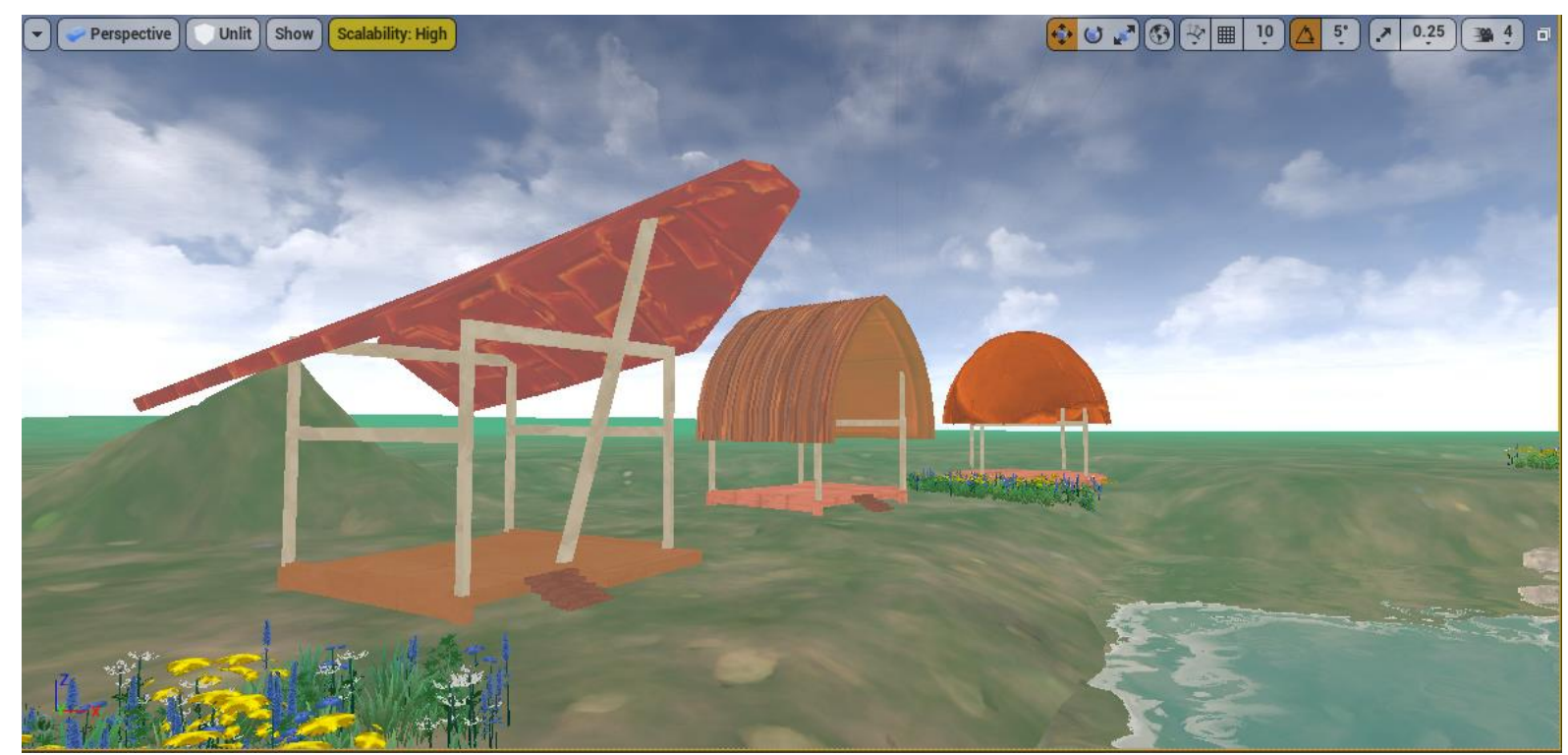

Gambar 19 . Render Unreal Engine (Sumber: Dokumentasi Pribadi, 2021) 


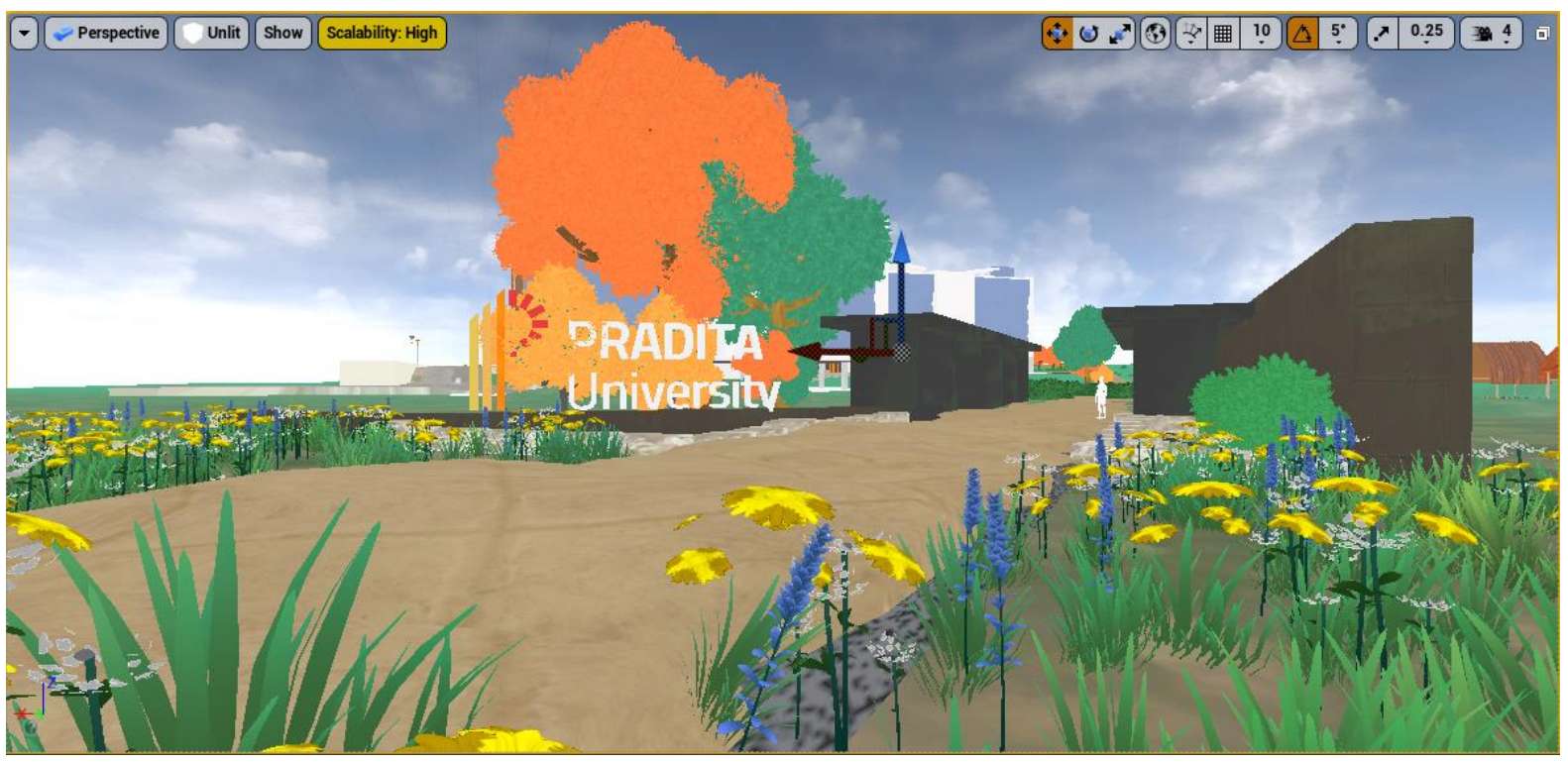

Gambar 20 . Render Unreal Engine (Sumber: Dokumentasi Pribadi, 2021)

\section{Unreal Engine}

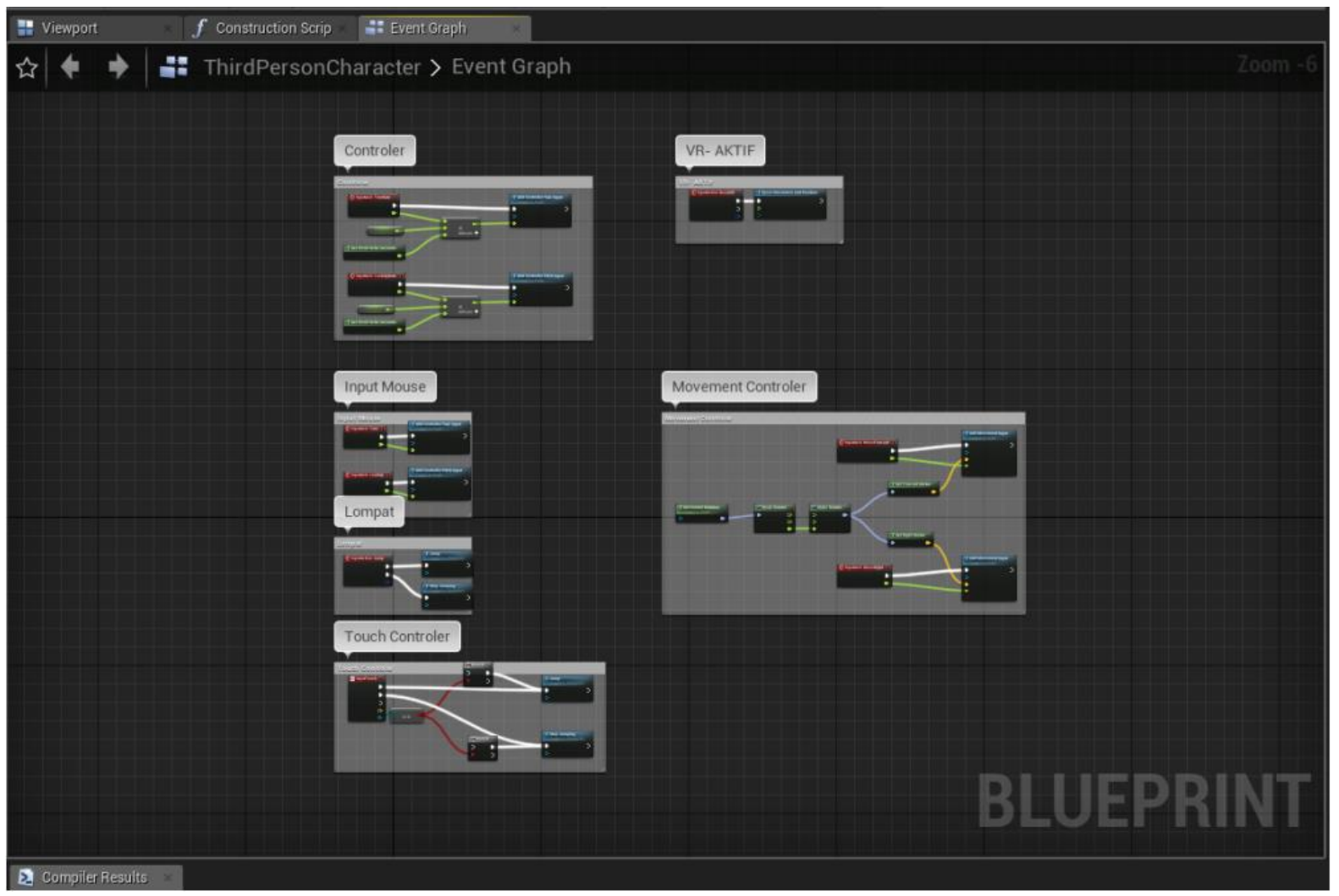

Gambar 21 . Blueprint Coding (Sumber: Dokumentasi Pribadi, 2021) 


\subsection{Pembahasan}

\section{What to say}

Penulis ingin mengkomunikasikan fasilitas akademik seperti gedung, lapangan, parkiran, ruang kelas, perpustakaan, Universitas Pradita dan hal-hal terkait spasial secara interaktif melalui media $3 D$ virtual environment

\section{How to say}

- Merancang point-to-point untuk user dengan cara memberikan tugas objektif yang bertujuan untuk memperkenalkan Universitas Pradita.

- Merancang signage sebagai pop-up interaction untuk menjelaskan kepada user mengenai gambar asli Universitas Pradita

- Merancang minimap dalam virtual environment.

- Menambahkan audio visual untuk menjelaskan tempat tertentu

\section{Hasil Perancangan}

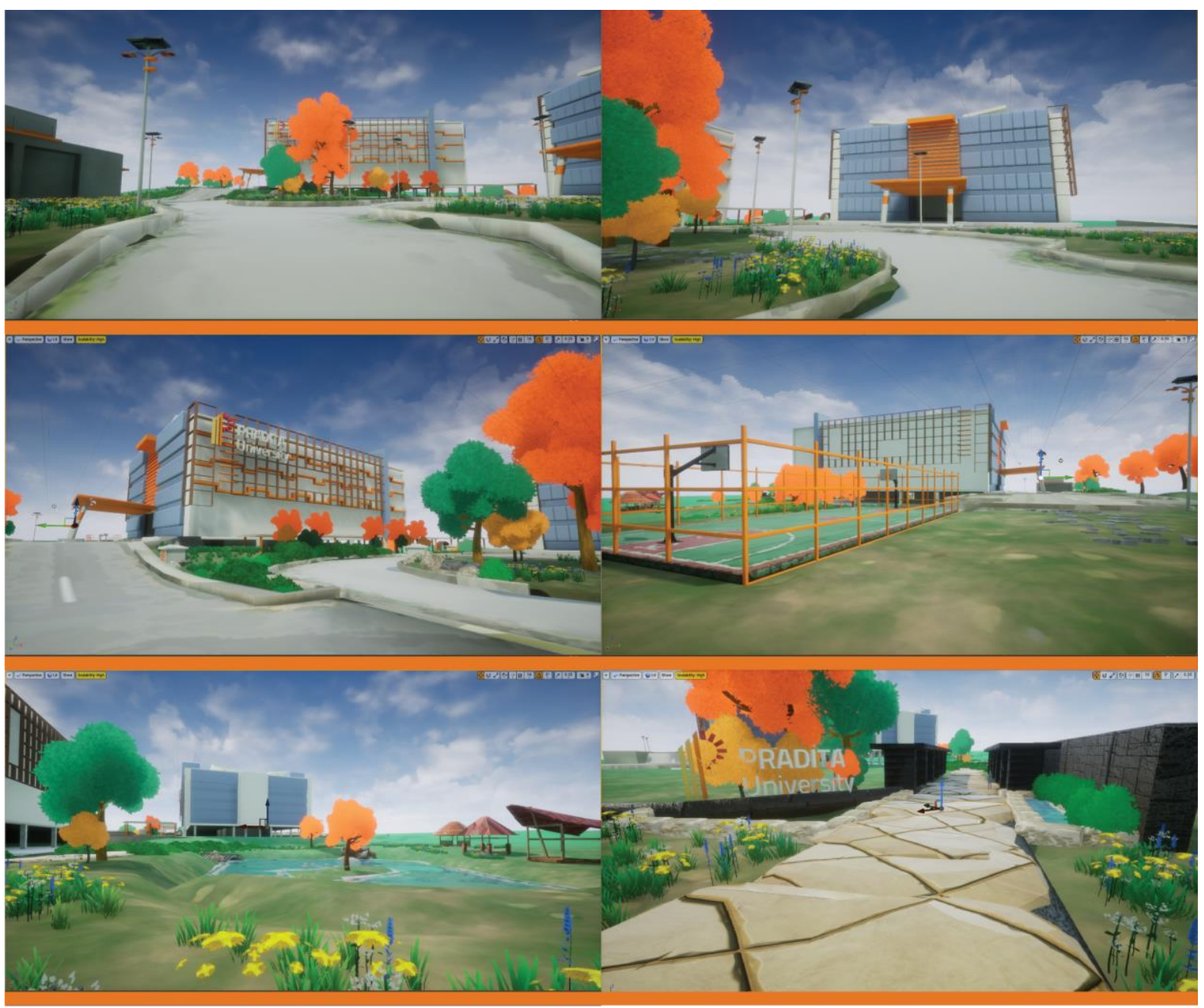

Gambar 22 . Hasil Akhir Desain Virtual Environment (Sumber: Dokumentasi Pribadi, 2021) 
Hasil akhir render menggunakan Unreal Engine berupa aplikasi Windows berupa virtual environment berbasis 3D interaktif.

\section{Titilium Font}

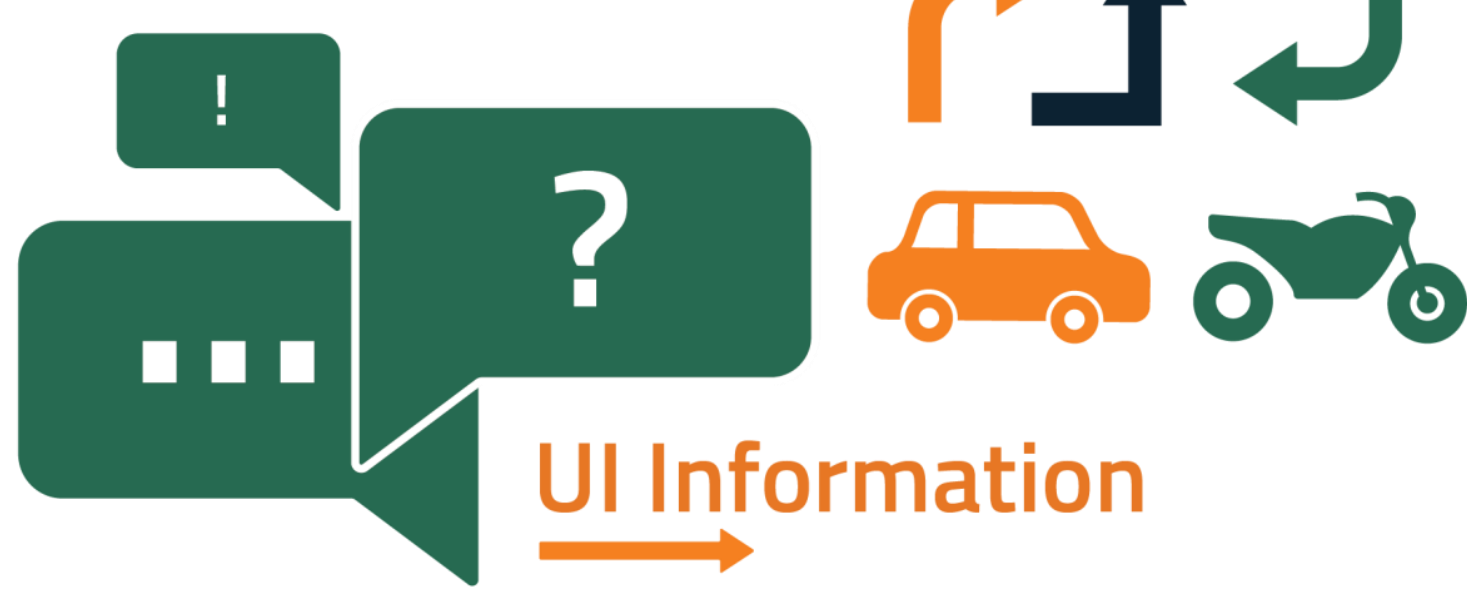

Gambar 23 . Hasil Akhir Desain Signage untuk Wayfinding (Sumber: Dokumentasi Pribadi, 2021)

Hasil pengembangan desain signage dari Identitas Universitas Pradita digunakan sebagai wayfinding dan popup interaction untuk mengkomunikasikan informasi fasilitas akademik

\section{KESIMPULAN}

Strategi komunikasi Universitas Pradita dalam menyampaikan fasilitas akademik masih menggunakan media non-interaktif seperti website, media sosial dan Youtube secara daring. Teknologi virtual yang tengah berkembang ditambah media tersebut tidak dapat merepresentasikan informasi fasilitas akademik yang terkait dengan hal-hal spasial serta tidak memiliki interaksi umpan balik terhadap user. Belum adanya media interaktif yang memiliki orientasi tujuan kepada user untuk bisa mengetahui fasilitas akademik secara lingkungan.Kondisi khusus seperti jarak tempat tinggal dan pandemi Covid-19 membatasi gerak masyarakat dalam ruang publik, sehingga masyarakat terhambat untuk mengakses tempat Universitas Pradita secara langsung.

Media 3D Virtual Environment Universitas Pradita setidaknya dapat merepresentasikan dengan baik kepada user mengenai hal-hal spasial secara virtual dengan nilai imersif. User dapat mengetahui letak bangunan fasilitas akademik, suasana dan gambaran lingkungan Universitas Pradita. Fitur view first person camera dapat membantu user dalam mengakses lingkungan Universitas Pradita secara virtual.

Pada tahapan produksi peneliti diharuskan untuk meminimalisir deformasi bentuk bangunan asli dengan bangunan aset 3D. Pertahankan nilai konsisten visual terkait signage bisa lebih berkomunikasi kepada user serta dari sisi pengembangan virtual environment bisa diakses secara multi-platform. Penulis juga harus mulai mengembangkan interior dalam bentuk aset 3D untuk memfinalisasi perancangan virtual environment. 


\section{DAFTAR PUSTAKA}

- Referensi dari jurnal

[1] Agung Pandawana, I Dewa Gede. RANCANG BANGUN MEDIA INFORMASI INTERAKTIF BERBASIS ANDROID SEBAGAI MEDIA INFORMASI PROGRAM STUDI STMIK STIKOM INDONESIA, vol. vol. 2, no. Vol. 2 No. 1 (2018): Jurnal Bahasa Rupa Oktober 2018, 2018-10-28, https://ejournal.stikiindonesia.ac.id/index.php/jurnalbahasarupa/article/view/237.

- Referensi dari jurnal

[2] Agustono, Leonard Adiwena, et al. PERANCANGAN MEDIA INTERAKTIF PENGENALAN LOBBY GEDUNG Q UK.PETRA BERUPA VIRTUAL WALKTHROUGH, 2020 .

- Referensi dari buku

[3] Calori, Chris, and David Vanden Eynden. Signage and Wayfinding Design. Second Edition ed., Canada, John Wiley \& Sons, Inc., Hoboken, New Jersey, 2015, www.wiley.com/go/permissions.

- Referensi dari buku

[3] Catanese, Salvatore, et al. "A Framework for Designing 3D Virtual Environments." A Framework for Designing 3D Virtual Environments, vol. vol 78, 2012, https://doi.org/10.1007/978-3-642-30214-5 23.

- Referensi dari jurnal

[4] Ellis, Stephen R. "What are Virtual Environments." What are Virtual Environments, IEEE Computer Graphics and Applications, 01 January 1994, https://dl.acm.org/doi/10.1109/38.250914.

- Referensi dari jurnal

[4] Kholiq, Ahmad Nur. Perancangan Simulasi Virtual Tour Perpustakaan Sunan Kalijaga Menggunakan Unity Game, 2016.

- Referensi dari disertasi

[5] Mari, Marisse. The Cel Shading Technique, 2012. 
- Referensi dari jurnal

[6] Nazir, Salman, et al. "22nd European Symposium on Computer Aided Process

Engineering." Virtual Environments, vol. Virtual Reality and Augmented-Virtual Reality as Tools to Train Industrial Operators, 2012, Pages 1397-1401.

- Referensi dari jurnal

[6] Prasetyanto, Anselmus Aris Budi. ANALISIS DAN PERANCANGAN 3D MODELLING KARAKTER DAN BACKGROUND GAME THE HERO OF MAJAPAHIT MENGGUNAKAN METODE SUBDIVISION MODELLING \& DIGITAL SCULPTING, 2014, pp. 13-14. 